\title{
PERILAKU SEDENTARI SISWA SMP DI KECAMATAN CIBINONG KABUPATEN BOGOR JAWA BARAT TAHUN 2018
}

\section{Sedentary Behavior of Junior High School Students in Cibinong Sub-District Bogor Regency West Java 2018}

\author{
Yunita Arihandayani ${ }^{1}$, Evi Martha ${ }^{1}$ \\ ${ }^{1}$ Departemen Pendidikan Kesehatan dan Ilmu Perilaku Fakultas Kesehatan Masyarakat Universitas \\ Indonesia, Kampus Baru UI Depok 16424, Indonesia \\ Email: evie.martha@ui.ac.id
}

Diterima: 16 Januari 2020; Direvisi: 28 Mei 2020; Disetujui: 25 Juni 2020

\begin{abstract}
The proportion of sedentary behavior is increasing in all age groups, both in adults and children, from year to year. Various adverse health effects in children and adolescents can occur due to sedentary behavior carried out continuously over a long period of time. Several factors are associated with the practice of sedentary behavior in children and adolescents. This study aims to determine factors associated with sedentary behavior in junior high school students in Cibinong sub-district, Bogor regency, West Java province. The research used cross sectional study design with 312 junior high school students of 7th and 8th grade. Data were collected using questionnaires that had been pre-tested for validity and reliability and were analyzed using chi-square test and multiple logistic regression in SPSS. The results showed $50.6 \%$ of respondents performed sedentary behavior more than 6 hours. Age $(O R=1.9)$, peer support $(O R=1.8)$ and school facilities $(O R=0.2)$ were associated with sedentary behavior. Students who are older, do not have peer support, and attend school with insufficient facilities are more likely to conduct sedentary behavior. For that reason, in order to prevent sedentary behavior among students, it is important to consider the age of the student, the fulfillment of adequate school facilities and the presence of peer support among students.
\end{abstract}

Keywords: Sedentary behavior, student, parenting patterns, school regulations and facilities

\begin{abstract}
ABSTRAK
Proporsi perilaku sedentari semakin meningkat pada semua kelompok umur, baik pada orang dewasa dan anak-anak, dari tahun ke tahun. Pada anak-anak dan remaja, berbagai dampak kesehatan merugikan dapat terjadi akibat perilaku sedentari yang dilakukan secara terus menerus dalam jangka waktu lama. Beberapa faktor berhubungan dengan terjadinya perilaku sedentari pada anak-anak dan remaja. Penelitian ini bertujuan untuk mengetahui faktor-faktor yang berhubungan dengan perilaku sedentari pada siswa SMP di Kecamatan Cibinong, Kabupaten Bogor, Provinsi Jawa Barat. Penelitian menggunakan desain cross sectional dengan jumlah sampel sebanyak 312 siswa SMP kelas 7 dan kelas 8. Data dikumpulkan menggunakan kuesioner yang sudah diuji validitas dan reliabilitasnya serta dianalisis menggunakan regresi logistik ganda. Sebanyak 50,6\% responden melakukan perilaku sedentari lebih dari 6 jam. Hasil analisis membuktikan faktor umur $(\mathrm{OR}=1,9)$, dukungan teman sebaya $(\mathrm{OR}=1,8)$, dan fasilitas sekolah $(\mathrm{OR}=0,2)$ berhubungan dengan perilaku sedentari. Ini artinya bahwa siswa dengan usia lebih tua, yang tidak memiliki dukungan teman sebaya, dan yang bersekolah di sekolah dengan fasilitas kurang memadai kemungkinan lebih besar untuk berperilaku sedentari. Untuk itu, dalam upaya pencegahan perilaku sedentari pada siswa, perlu diperhatikan umur siswa, pemenuhan fasilitas sekolah yang memadai serta adanya dukungan teman sebaya dalam pergaulan siswa.
\end{abstract}

Kata kunci: Perilaku sedentari, siswa, pola asuh, fasilitas sekolah, peraturan sekolah 


\section{PENDAHULUAN}

Sedentary life style merupakan kehidupan dengan aktivitas fisik yang sangat kurang serta penyimpangan pola makan dimana asupan cenderung tinggi energi (lemak, protein dan karbohidrat) dan rendah serat (Hadi, 2007). Secara global, dibandingkan beberapa tahun lalu terjadi peningkatan perilaku sedentari pada anak dan remaja (Salmon et al., 2018). Pada anak -anak dan remaja perilaku sedentari ini sering dikaitkan dengan kejadian kelebihan berat badan dan obesitas (Inyang, 2015). Obesitas pada anak-anak dan remaja berisiko munculnya resistensi insulin yang menyebabkan diabetes tipe 2 (Carson et al., 2016). Risiko kesehatan lainnya dari obesitas pada anak-anak meliputi batu empedu dan penyakit kardiovaskular (Suchert et al., 2015). Penelitian lain juga menyebutkan bahwa menonton televisi lebih dari 2 jam per hari menyebabkan rendahnya tingkat kebugaran pada anak dan remaja (Wickel et al., 2013).

Tidak hanya gangguan fisik, perilaku sedentari yang dilakukan secara berkepanjangan oleh anak dan remaja akan menyebabkan gangguan kesehatan mental dan emosional seperti hiperaktif/tidak konsentrasi, agresif, ketidakmampuan menginternalisasi masalah, depresif, dan penurunan kualitas hidup yang dirasakan rata-rata menghabiskan waktu 8 jam per hari (Stierlin et.al., 2015).

$\begin{array}{cccc}\text { Di } & \text { Indonesia } & \text { berdasarkan } & \text { Riset } \\ \text { Kesehatan } & \text { Dasar } & \text { (Riskesdas) } & 2013\end{array}$ menunjukkan bahwa 1 dari 4 penduduk Indonesia melakukan perilaku sedentari lebih dari 6 jam per hari. Proporsi perilaku sedentari lebih dari 6 jam per hari cukup tinggi pada anak usia 10-14 tahun yaitu sebesar 29,1\%. Di Kabupaten Bogor persentase penduduk yang melakukan perilaku sedentari lebih dari 6 jam per hari yaitu sebanyak $32 \%$ dengan kelompok terbanyak pada anak dan remaja usia 10-14 tahun sebesar 40,5\% (Kemenkes RI, 2013).

Tingginya perilaku sedentari pada anak-remaja dipengaruhi oleh banyak faktor. Stierlin dan kawan-kawan (2015) mengklasifikasikan faktor determinan perilaku sedentari dalam empat tingkatan menggunakan kerangka kerja ekologis sosial. Empat tingkatan itu terdiri dari tingkat individu (umur, jenis kelamin, sosio ekonomi) tingkat interpersonal (keluarga, teman sebaya, teman kerja), tingkat lingkungan (sekolah, tempat kerja, dll) dan tingkat kebijakan (industri, pemerintah) (Barkley et al., 2012).

Berdasarkan data dan adanya permasalahan diatas peneliti tertarik untuk melakukan penelitian tentang perilaku sedentari pada siswa SMP di Kecamatan Cibinong Kabupaten Bogor Jawa Barat tahun 2018.

\section{BAHAN DAN CARA}

Penelitian ini merupakan penelitian kuantitatif dengan desain cross sectional yang dilaksanakan pada bulan Mei 2018 di Kecamatan Cibinong Kabupaten Bogor. Populasi adalah seluruh siswa SMP di Kecamatan Cibinong Kabupaten Bogor yaitu sebanyak 16.542 siswa dengan sampel sebanyak 312 siswa yang dipilih secara random dari 7 SMP dan sederajat yaitu terdiri dari 2 SMP negeri, 2 SMP swasta, 1 MTs negeri dan 2 MTs swasta. Kriteria inklusi adalah siswa-siswi aktif dan bersedia menjadi responden, sedangkan siswa kelas tiga di ekslusi dalam penelitian ini karena kesibukan mempersiapkan Ujian Nasional.

Pengumpulan data dilakukan menggunakan kuesioner yang diisi secara mandiri oleh responden (self-administered), namun sebelumnya peneliti menjelaskan lebih dulu kepada responden tentang tata cara pengisian kuesioner. Setiap responden mengisi inform consent sebagai kesediaan menjadi responden. Kuesioner terdiri dari pertanyaan tentang perilaku sedentari, sikap terhadap perilaku sedentari, dukungan teman sebaya dan fasilitas sekolah. Kuesioner untuk variabel dependen (perilaku sedentari) mengacu pada The Adolescent Sedentary Activity Questionnaire (ASAQ) dari The Australasian Child and Adolescent Obesity Research Network (ACAORN). Data dianalisis menggunakan uji chi-square dan regresi logistik ganda.

Beberapa penelitian tentang perilaku sedentari menggunakan cut off points $<3$ jam, 3-5,9 jam dan $\geq 6$ jam. Penelitian ini 
mengukur perilaku sedentari $\geq 6$ jam merujuk pada hasil penelitian yang menyebutkan bahwa perilaku sedentari $>6$ jam per hari beresiko lebih tinggi terkena beberapa penyakit degeneratif seperti kanker, hipertensi dan penyakit pembuluh darah lainnya dibandingkan perilaku sedentari $>3$ jam per hari (Inyang, 2015).

Sebelum pengumpulan data di lapangan telah dilakukan kaji etik sesuai prosedur di Fakultas Kesehatan Masyarakat Universitas Indonesia. Proposal penelitian telah mendapat persetujuan oleh Komite Etik Riset dan Pengabdian Kesehatan Masyarakat Fakultas Kesehatan Masyarakat Universitas Indonesia melalui Surat Keterangan Nomor 430/UN2.F10/PPM.00.02/2018 tanggal 14 Mei 2018.

\section{HASIL}

Responden dalam penelitian ini lebih banyak siswa perempuan yang berjumlah 183 siswa $(58,7 \%)$ sedangkan siswa laki-laki berjumlah 129 siswa $(41,3 \%)$ dengan umur siswa $>13$ tahun sebanyak 166 siswa $(53,2 \%)$ dan siswa dengan umur $\leq 13$ tahun sebanyak $146(46,8 \%)$ (Tabel 1). Dalam penelitian ini, umur responden dikelompokkan menjadi 2 kelompok umur, yaitu $\leq 13$ tahun dan $>13$ tahun. Pembagian umur ini karena umur 1315 tahun merupakan masa remaja awal yang masih terjadi pertumbuhan dan perkembangan fisik dan psikologik yang cukup pesat pada seorang anak (Purwanti, 2015).

Tabel 1. Karakteristik Umum Responden

\begin{tabular}{lrr}
\hline \multirow{2}{*}{ Karakteristik Umum } & Jumlah & Persentase \\
\cline { 2 - 3 } & \multicolumn{1}{c}{$\mathrm{N}$} & $\%$ \\
\hline Umur & & \\
$\leq 13$ tahun & 146 & 46,8 \\
$>13$ tahun & 166 & 53,2 \\
Jenis Kelamin & & \\
laki-laki & 129 & 41,3 \\
perempuan & 183 & 58,7 \\
\hline
\end{tabular}

Hasil penelitian didapatkan bahwa siswa SMP di Kecamatan Cibinong, Kabupaten Bogor dengan rentang usia responden antara umur 11-15 tahun yang melakukan perilaku sedentari $\geq 6 \mathrm{jam} / \mathrm{hari}$ sebanyak 158 siswa $(50,6 \%)$ dan sebanyak 154 siswa $(49,4 \%)$ yang melakukan perilaku sedentari $<6$ jam/hari (Gambar 1).

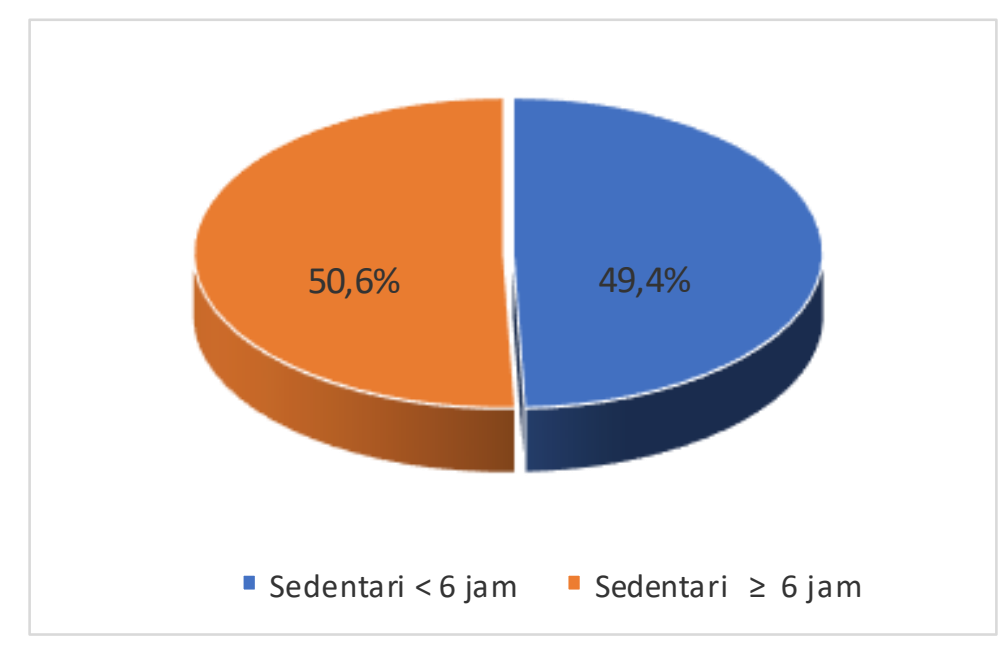

Gambar 1. Kategori perilaku sedentari 
Tabel 2 memberikan informasi bahwa jenis aktivitas perilaku sedentari terbanyak yang dilakukan oleh siswa di luar jam sekolah adalah menonton televisi $(21,7)$, duduk duduk sambil berbincang/mengobrol dengan teman/bercanda/telepon/chatting di telepon/duduk-duduk santai $(15,8 \%)$ bermain menggunakan komputer untuk kesenangan : main games, browsing, chatting, dll (14,7\%). Sedangkan jenis aktivitas perilaku sedentari yang terendah adalah aktivitas duduk memainkan alat musik sebesar $2,3 \%$.

Tabel 2. Jenis aktifitas perilaku sedentari pada siswa SMP di Kecamatan Cibinong, Kabupaten Bogor Jawa Barat, Tahun 2018

\begin{tabular}{lrrr}
\hline \multicolumn{1}{c}{ Aktivitas Perilaku Sedentari } & $\begin{array}{c}\text { Jumlah rata-rata } \\
\text { menit per hari } \\
\text { (n) }\end{array}$ & $\begin{array}{c}\text { Persentase } \\
\text { Responden } \\
(\%)\end{array}$ \\
\hline Menonton TV & 591 & 21,7 \\
$\begin{array}{l}\text { Duduk duduk sambil berbincang/mengobrol dengan } \\
\text { teman/bercanda/telepon/chatting di telepon/duduk-duduk }\end{array}$ & 512 & 15,8 \\
$\begin{array}{l}\text { santai } \\
\text { Bermain menggunakan Komputer untuk kesenangan: main }\end{array}$ & & \\
games, browsing, chatting, dll & 403 & 14,7 \\
Mengerjakan PR tanpa komputer & & \\
Menonton video/DVD & 277 & 10,1 \\
Membaca untuk kesenangan & 222 & 8,2 \\
$\begin{array}{l}\text { Duduk mengerjakan kerajinan tangan atau hal yang } \\
\text { berkaitan dengan hobi }\end{array}$ & 187 & 6,9 \\
$\begin{array}{l}\text { Duduk menggunakan transportasi (mobil,bus,kereta) } \\
\text { Menggunakan komputer untuk mengerjakan PR }\end{array}$ & 159 & 5,8 \\
Mengikuti les diluar jam sekolah & & 146 & 5,3 \\
Duduk memainkan alat musik misal ; piano, gitar, dll & 92 & 3,4 \\
\end{tabular}

Tabel 3, menunjukkan hasil analisis bivariat perilaku sedentari, hasil analisis umur siswa sedentari $(\mathrm{p}=0,005 ; \mathrm{OR}=1,9$; $95 \%$ CI $=1,2-3)$ berhubungan dengan perilaku sedentary, sedangkan Tabel 4 memperlihatkan hasil analisa data multivariat yang menyatakan nilai OR untuk variabel umur $=1,9$ artinya siswa-siswi yang umur di atas 13 tahun memiliki peluang kemungkinan 1,9 kali untuk melakukan perilaku sedentari $\geq 6$ jam/hari dibandingkan siswa-siswi yang umur di bawah 13 tahun.

Hasil penelitian juga menunjukan bahwa dukungan teman sebaya $(\mathrm{p}=0,009$; $\mathrm{OR}=1,8 ; 95 \% \quad \mathrm{CI}=1,2-2,9)$ berhubungan dengan perilaku sedentari. Dari penelitian ini diketahui bahwa sebagian besar siswa memiliki dukungan teman sebaya $(50,9 \%)$ dan sisanya sebanyak $49,1 \%$ tidak memiliki dukungan teman sebaya. 
Tabel 3. Hasil analisis bivariat perilaku sedentari pada siswa SMP di Kecamatan Cibinong, Kabupaten Bogor Jawa Barat Tahun 2018

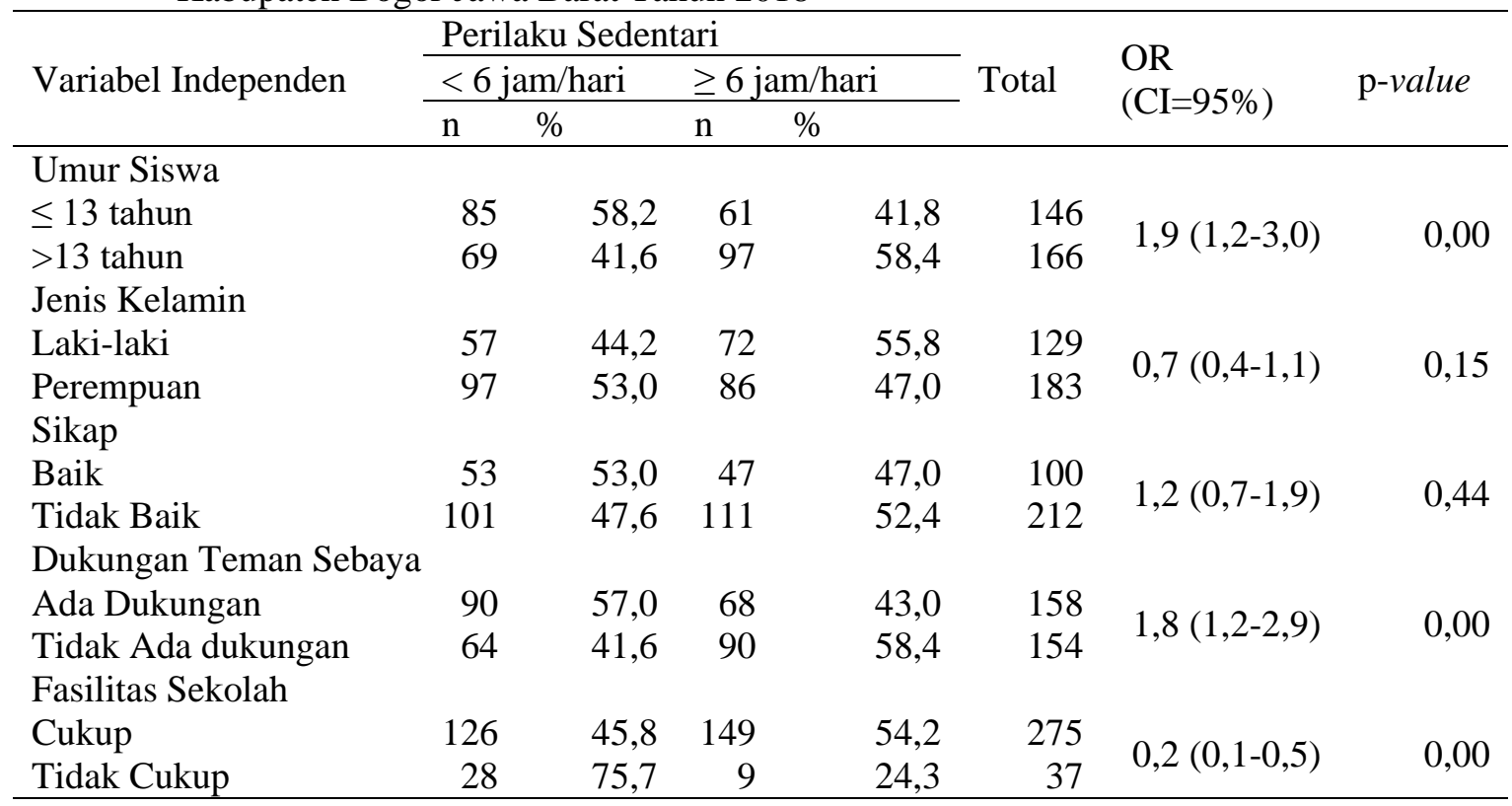

Hasil penelitian menunjukkan fasilitas sekolah $(\mathrm{p}=0,001 ; \mathrm{OR}=0,2 ; 95 \% \mathrm{CI}=$ $0,1-0,5)$ berhubungan dengan perilaku sedentari. Hasil analisis multivariat diperlihatkan pada Tabel 4 yang menyatakan nilai OR untuk variabel fasilitas sekolah adalah 0,2 artinya sekolah yang tidak menyediakan fasilitas sekolah yang cukup memadai kemungkinan siswa-siswinya 0,2 kali melakukan perilaku sedentari $\geq 6$ jam/hari dibandingkan siswa-siswi yang bersekolah dengan fasilitas sekolah yang memadai.

Tabel 4. Hasil Analisis Multivariat Perilaku Sedentari pada siswa SMP di kecamatan Cibinong Kabupaten Bogor Jawa Barat tahun 2018

\begin{tabular}{lc}
\hline Variabel & Nilai Odds Ratio (OR) \\
\hline Umur & 1,9 \\
Dukungan Teman Sebaya & 1,8 \\
Fasilitas Sekolah & 0,2 \\
\hline
\end{tabular}

Fasilitas sekolah yang cukup memadai untuk menghindari perilaku sedentari siswa-siswinya antara lain : fasilitas tempat parkir sepeda, adanya trotoar untuk berjalan kaki, adanya tempat penyebrangan di depan sekolah beserta petugasnya dan adanya tempat yang bisa digunakan bermain saat jam istirahat sekolah.

\section{PEMBAHASAN}

Hasil Penelitian yang terlihat pada gambar 1 sesuai dengan hasil dari 14 studi yang dirangkum oleh Ekelund dkk., menunjukkan rata-rata perilaku sedentari yang dilakukan oleh anak-anak dan remaja adalah lebih dari 6 jam (Ekelund et al., 2012), sedangkan hasil penelitian oleh Mitchell dkk, didapatkan bahwa anak-anak menghabiskan waktu mereka rata-rata 7 jam sehari melakukan perilaku sedentari (Mitchell et al., 2009). Jumlah ini melebihi waktu yang direkomendasikan yakni 2 jam sehari untuk mengurangi dampak negatifnya terhadap kesehatan (Chung et al., 2017).

Jenis aktivitas perilaku sedentari yang dilakukan responden dalam penelitian ini sesuai dengan penelitian yang dilakukan pada siswa SD umur 10-12 tahun di Kota Denpasar yang menyebutkan bahwa aktivitas 
perilaku sedentari terbanyak yang dilakukan siswa SD adalah menonton televisi, sedangkan aktivitas perilaku sedentari yang paling jarang salah satunya adalah memainkan alat musik (Risna, 2016). Sejalan juga dengan penelitian yang dilakukan oleh Dwi pada siswa SD di Surabaya yang mana pada anak usia 9-11 tahun di SDN Kedurus III/430 Kelurahan Kedurus Kecamatan Karang Pilang Surabaya, memiliki perilaku sedentari sering sebanyak $(75 \%)$ dan sisanya memiliki perilaku sedentari jarang sebanyak (25\%).

Sebagian besar waktu luang anak digunakan untuk menonton televisi, bermain komputer atau video games, duduk/tiduran sambil mendengarkan musik, duduk/tiduran sambil menerima telepon, duduk/tiduran sambil ngemil, duduk/tiduran sambil baca buku/majalah, bermain musik, membuat kerajinan, duduk/tiduran sambil main handphone. Hal tersebut dapat terjadi karena orang tua saat ini kurang percaya atau kurang merasa aman apabila anaknya bermain diluar rumah atau bermain dengan teman sebayanya. Orang tua juga kurang meluangkan waktu untuk menghabiskan waktu bersama anak dengan bermain bersama anak, melakukan olahraga bersama atau kegiatan lain yang lebih membutuhkan pengeluaran energi (Ramadhani, 2017)

Beberapa negara maju seperti Kanada, Australia, Jerman dan beberapa negara maju lainnya telah merekomendasikan bahwa seorang anak dan remaja harus membatasi waktu sedentari dalam transportasi, duduk lama dan menghabiskan waktu dalam ruangan sepanjang hari maksimal kurang dari 2 jam per hari (Mozafarian et al., 2017).

Rekomendasi terutama menekankan pada waktu yang dihabiskan untuk melihat monitor/screen time yang dibatasi maksimal 2 jam per hari. Beberapa penelitian menunjukkan hubungan antara waktu menonton televisi dengan obesitas pada anak-anak, hal ini disebabkan karena selain pengeluaran energi yang terbatas juga karena anak-anak yang lebih banyak menonton TV juga memiliki asupan energi yang lebih tinggi dari camilan lemak, manis dan asin, dan minuman berenergi tinggi serta konsumsi buah dan sayuran yang lebih rendah. Selain itu paparan televisi yang cukup lama dapat menyebabkan perkembangan kognitif yang lebih buruk, memori jangka pendek, pencapaian akademik dan keterampilan bahasa, dan lebih sedikit kata dalam vocabulari anak-anak (Salmon et al., 2011)

Pada Table 3 menunjukkan umur siswa berhubungan dengan perilaku sedentari. Hasil penelitian ini sejalan dengan studi kohort yang dilakukan pada 886 siswa usia 9-11 tahun di Irlandia bahwa dengan bertambahnya usia semakin meningkat perilaku sedentari anak di luar jam sekolah ( Wickel et al., 2013). Demikian pula hasil penelitian studi kohort selama 5 tahun di Inggris pada siswa usia 11-12 tahun menunnjukkan terjadinya peningkatan perilaku sedentari ketika mereka berusia 1516 tahun (Brodersen et al., 2007). Namun hal berbeda didapatkan dari hasil Riskesdas 2013 yang menyebutkan bahwa umur 11- 14 tahun lebih banyak melakukan perilaku sedentari $\geq$ 6 jam/hari yaitu 29,1\% dibandingkan umur $15-19(25,5 \%)$.

Siswa yang tidak memiliki dukungan teman sebaya lebih berpeluang untuk melakukan perilaku sedentari. Hal ini didukung hasil penelitian yang dilakukan oleh Chung, Ersig dan McCarthy (2017), bahwa pada masa remaja, teman sebaya mempengaruhi aktivitas fisik seseorang seperti olahraga. Semakin dekat dan akrab hubungan pertemanan yang terjalin, maka semakin mirip perilaku seseorang dengan temannya. Oleh karena itu teman dekat cenderung lebih mudah mempengaruhi dalam melakukan aktivitas fisik seperti berolahraga. Teman dekat yang dimaksud adalah teman yang sering menghabiskan waktu bersama biasanya yang memiliki gender yang sama, dan mendukung satu sama lain (Chung et al., 2017).

Hal ini sejalan dengan hasil sebuah penelitian yang dilakukan di Kent University Amerika Serikat bahwa tidak adanya penerimaan oleh teman sebaya akan meningkatkan perilaku sedentari siswa yaitu seorang anak yang dikucilkan dalam kelompok bermain akan menghabiskan waktu sedentari lebih banyak dibandingkan anak yang tidak mendapat perlakuan 
pengucilan ( Barkley et al., 2012). Penelitian pada siswa usia 13-15 tahun di negara ASEAN menyatakan bahwa siswa yang tidak memiliki kelompok teman sebaya cenderung lebih tinggi melakukan perilaku sedentari (Healy et al., 2008).

Berdasarkan hasil beberapa penelitian diatas bahwa pendekatan melalui peer support bisa menjadi salah satu alternatif intervensi yang cukup efektif dalam program upaya pencegahan perilaku sedentari pada anak dan remaja.Dari hasil penelitian yang menunjukkan fasilitas sekolah berhubungan dengan perilaku sedentari, bahwa tersedianya fasilitas membuat aktivitas fisik semakin meningkat, karena fasilitas merupakan salah satu yang mendukung seseorang untuk melakukan aktivitas fisik dan mencegah sedentari. Adanya fasilitas yang cukup memadai, akan memberi kemudahan bagi seseorang untuk melakukan kegiatan aktivitas fisik (Colley et al., 2011) Hal ini sejalan dengan penelitian yang dilakukan pada 839 siswa usia 9-11 tahun di sekolah Inggris diketahui bahwa adanya fasilitas sekolah seperti jalur yang aman untuk bersepeda, petugas penyebrangan dan tempat penyebrangan yang aman bagi siswa dapat mencegah perilaku sedentari pada anak (Mantjes et al., 2012).

Berdasarkan hal diatas diketahui bahwa fasilitas sekolah mempunyai peran yang sangat penting dalam mencegah perilaku sedentari siswa sehingga salah satu upaya advokasi dan sosialisasi pencegahan perilaku sedentari pada anak dan remaja perlu menekankan ketersediaan fasilitas sekolah yang cukup.

\section{KESIMPULAN DAN SARAN}

\section{Kesimpulan}

Perilaku sedentari siswa SMP di Kecamatan Cibinong Kabupaten Bogor Jawa Barat tahun 2018 masih tergolong cukup tinggi. Faktor umur, dukungan teman sebaya, dan fasilitas sekolah berhubungan dengan perilaku sedentari. Siswa umur lebih dari 13 tahun lebih berpeluang melakukan perilaku sedentari dibandingkan siswa umur kurang 13 tahun. Siswa yang tidak memiliki dukungan teman sebaya kemungkinan lebih besar melakukan perilaku sedentari dibandingkan siswa yang memiliki dukungan teman sebaya. Siswa yang bersekolah di sekolah dengan fasilitas kurang memadai kemungkinan lebih besar melakukan perilaku sedentari dibandingkan siswa yang bersekolah di sekolah dengan fasilitas yang cukup memadai.

\section{Saran}

Kementerian Kesehatan perlu mengembangakan strategi komunikasi untuk mencegah peningkatan perilaku sedentari pada anak dan remaja dengan pendekatan di beberapa tingkat yaitu tingkat individu, tingkat interpersonal dan tingkat komunitas. Dinas Kesehatan Kabupaten Bogor perlu menjalin koordinasi dengan lintas sektor Dinas Pendidikan dan Dinas Agama dan melibatkan peer support untuk mencegah peningkatan perilaku sedentari pada anak dan remaja. Selain itu, pihak sekolah perlu menyediakan fasilitas sekolah mendukung pencegahan perilaku sedentari pada siswa.. Kepada peneliti selanjutnya disarankan untuk melakukan penelitian sejenis dengan menggunakan metode kualitatif untuk mendapatkan alasan lebih mendalam yang mendorong anak dan remaja melakukan perilaku sedentari.

\section{DAFTAR PUSTAKA}

Barkley JE, Salvy S-J, Roemmich JN, Heo M, Pietrobelli A. (2012). The effect of simulated ostracism on physical activity behavior in children. Pediatrics, 129(3),659-666.

Brodersen NH, Steptoe A, Boniface DR, Wardle J, Hillsdon M. (2007) Trends in physical activity and sedentary behaviour in adolescence: ethnic and socioeconomic differences * commentary. Br J Sports Med ,41(3), 140-144

Burhanuddin Bahar H. (2012).Pola Konsumsi Sayur, Buah Dan Aktivitas Sedentari Mahasiswa Obesitas Di Universitas Hasanuddin.

Carson V, Hunter S, Kuzik N, Gray CE, Poitras VJ, Chaput J-P, et al. (2016). Systematic review of sedentary behaviour and health indicators in school-aged children and youth: an update 1. Appl Physiol Nutr Metab,41,240-265.

Chung, S.J., Ersig, A.L., \& McCarthy, A.M. (2017). The influence of peers on diet and exercise among adolescents: a systematic review. Journal of Pediatric Nursing ,36(1), 44-45. 
Colley RC, Garriguet D, Janssen I, Craig C, Clarke J, Tremblay MS. (2011).Physical activity of Canadian children and youth: Accelerometer results from the 2007-2009 Canadian Health Measures Survey. Statistics Canada Catalogue no. 82-003-XPE Health Reports, 22(1), $1-9$

Ekelund U, Luan J, Sherar LB, Esliger DW, Griew P, Cooper A. (2012). Moderate to Vigorous Physical Activity and Sedentary Time and Cardiometabolic Risk Factors in Children and Adolescents. JAMA,307(7),704-712.

Hadi H. (2007). Beban Ganda Masalah Gizi dan Implikasinya terhadap Kebijakan Pembangunan Kesehatan Nasional. Yogyakarta : UGM.

Healy GN, Dunstan DW, Salmon J, Cerin E, Shaw JE, Zimmet PZ, et al.(2008). Breaks in Sedentary Time: Beneficial associations with metabolic risk. Diabetes Care,31(4),661-666.

Inyang MP. (2015). Sedentary Lifestyle: Health Implications. IOS. J Nurs Heal Sci Ver I.,4(2):2320-2340.

Kementerian Kesehatan Republik Indonesia. RISKESDAS. 2013.

Mantjes JA, Jones AP, Corder K, Jones NR, Harrison F, Griffin SJ, et al. (2012). School related factors and $1 \mathrm{yr}$ change in physical activity amongst 9-11 year old English schoolchildren. Int $\mathrm{J}$ Behav Nutr Phys, 9(1),153-159.

Mitchell JA, Mattocks C, Ness AR, Leary SD, Pate RR, Dowda M, dkk. (2009). Sedentary Behavior and Obesity in a Large Cohort of Children. OBESITY,17(8),1596-1602.

Mozafarian N, Motlagh M, Heshmat R, Karimi S, Mansourian M, Mohebpour F, et al. (2017).
Factors associated with screen time in Iranian children and adolescents: The CASPIAN-IV study. Int J Prev Med,8(1),31-39

Peltzer K, Pengpid S. (2018). Prevalence, risk awareness and health beliefs of behavioural risk factors for cardiovascular disease among university students in nine ASEAN countries.

Ramadhani DY . (2017). Aktivitas Fisik Dengan Perilaku Sedentari Pada Anak Usia 9-11 Tahun Di Sdn Kedurus Iii/430 Kelurahan Kedurus Kecamatan Karang Pilang Surabaya . Husada Nursing Journal, 3 (2),27-33

Risna Dea Pramita1 IPAG. (2016). Hubungan Antara Perilaku Sedentari Dengan Indeks Massa Tubuh Pada Siswa Kelas V Di Sd Cipta Dharma Denpasar. E-Jurnal Med Udayana, $5(2), 1-9$.

Salmon J, Tremblay MS, Marshall SJ, Hume C. (2014). Health Risks, Correlates, and Interventions to Reduce Sedentary Behavior in Young People. Am J Prev Med ,41(2):197-206.

Stierlin AS, De Lepeleere S, Cardon G, DargentMolina P, Hoffmann B, Murphy MH, et al. (2015). A systematic review of determinants of sedentary behaviour in youth: a DEDIPAC-study. Int J Behav Nutr Phys Act ,12(1):133-139.

Suchert V, Hanewinkel R, Isensee B. (2015). Sedentary behavior and indicators of mental health in school-aged children and adolescents: A systematic review. Prev Med (Baltim), 76(2),48-57.

Wickel EE, Issartel J, Belton S. (2013). Longitudinal Change in Active and Sedentary Behavior during the After-School Hours. J Phys Act Heal,10(3):416-422. 